\title{
HISTORIA DE VIDA, DE FAMILIA, Y DE GÉNERO SOBRE LA EMIGRACIÓN A BRASIL A COMIENZOS DEL SIGLO XX: DESDE LA ANDALUCÍA DEL MINIFUNDIO A LOS CAFETALES DE SAO PAULO.
}

\author{
Maria Dolores Pérez Murillo \\ Universidad de Cádiz
}

\section{$\underline{R E S U M E N}$}

El presente artículo recuerda la importancia de las fuentes orales como vía de conocimiento de la historia reciente de la emigración e historia de la familia en Brasil, en América Latina, en el siglo XX.

Palabras clave: América Latina. Brasil. Siglo XX. Historia de la Familia. Historia Oral.

\section{ABSTRACT}

This article shows the importance of the oral fonts for way for knowledge of the recent history of migration and history of family in Brasil, in Latin America, XXth century.

Keywords: Latin America. Brasil. XXth century. Family history. Oral history.

\section{INTRODUCCIÓN}

El presente artículo trata de reproducir textualmente un testimonio oral (de unos 45 minutos de duración) tomado en abril de 1992 en el anejo motrileño de Carchuna (Granada) a una mujer de 65 años de edad, proveniente del medio rural, concretamente del pueblo de Rubite, situado en la cordillera costera granadina en los límites con la provincia de Almería. La informante es gran conocedora de su entorno rural, pues, no en vano en el momento de la entrevista, la mayor parte de sus ingresos provenían de la posesión de algunas parcelas de invernadero en el poblado de colonización de Carchuna, parcelas que se remontan a finales de los años cincuenta y comienzos de los sesenta del siglo XX, fruto de los "planes de desarrollo" franquistas, planes que posibilitaron a muchos jomaleros tener una vivienda digna y una parcela de tierra en pueblos de colonización, cuyas tierras semidesérticas, situadas a las orillas del Mar Mediterráneo, se transformaron en 
cultivos de"enarenados" y de invernadero que, con el transcurrir del tiempo, a partir de los años setenta, fueron altamente rentables. De ello nos dan fe los invernaderos de las costas granadina y almeriense que, si bien atentan al medio ambiente, son una pingüe fuente de ingresos para familias que, en sus orígenes fueron muy humildes. Hoy, por azar del destino, algunos de los hijos y nietos de aquellos pobres muestran un sentir xenófobo frente a los indocumentados del norte de África y de América Latina que trabajan en condiciones infrahumanas bajo los "plásticos" de "sus" invernaderos.

Volviendo al tema que nos ocupa, la informante del presente testimonio, persona de grandes inquietudes humanas y totalmente autodidacta, a modo de relato literario, nos va narrando la historia de su familia materna, de su madre concretamente, nacida en 1901 y fallecida en 1984. Familia totalmente afectada por el éxodo emigratorio que las comarcas de la costa y de las sierras de Andalucía Oriental experimentan hacia Brasil en el último cuarto del siglo XIX y comienzos del XX. La autora de la presente "historia de vida" jamás visitó aquel país, pero ello no dificulta ni merma el valor real de su información. Ésta va referida a la emigración a Brasil que en 1906 realiza una familia constituida por el matrimonio y cinco hijos (cuatro mujeres y un varón). Una de las hijas de dicha familia, madre de la informante, con cinco años de edad, no emigra con sus padres, sino que se queda aquí, en la aldea de Rubite (Granada), encomendada a la tutela de sus abuelos maternos y de una tía materna, casada y sin hijos. Esto último posee una fuerte connotación dentro del imaginario socio-económico rural, pues dejar en la aldea a una hija pequeña, encomendada a su familia materna, significaba, en cierto modo, el continuismo y consolidación de los vínculos morales y materiales con el lugar de origen, era también una garantía de herencia del minifundio de sus padres más la herencia que le correspondiera de los abuelos (en el medio rural de la Andalucía minifundista, es normal que los nietos tutelados por abuelos se comprometan a cuidar a estos en la ancianidad, a cambio de recibir mejoras en la herencia, casi heredarán como un hijo más, lo cual generará abundantes pleitos entre padres e hijos, y hermanos entre sí.). En definitiva, dejar una hija en España era la mejor garantía de retorno, pues si no marchaban bien las cosas allende los mares, si no se lograba "hacer la América", siempre estaba la puerta abierta a los "orígenes" y al "futuro", al matriarcado rural. Las tierras de la aldea, Rubite, de la que parte esta unidad doméstica de campesinos minifundistas, son insuficientes para una familia numerosa, son tierras accidentadas, pobres y de secano, sometidas a un régimen pluviométrico irregular e inclemente.

La familia protagonista del presente testimonio embarcará en Málaga en 1906 rumbo al puerto de Santos (Brasil). Por aquella época el desplazamiento se hacía en vapores extranjeros que recalaban en puertos andaluces, en buena parte 
franceses que tocaban Málaga y Cádiz cada quince días aproximadamente. El ambiente que se vivía en la ciudad de Málaga, plataforma de emigración era de bastante conflictividad social, dada la crisis finisecular que se estaba experimentando en el agro andaluz desde la plaga de la filoxera, iniciada en 1878.

Superadas las vicisitudes del embarque y viaje, nuestra familia nuclear, constituida por seis miembros arribará al puerto de Santos, y desde aquí a la Hospedería de Inmigrantes de Sao Paulo, allí permanecerán unos cuantos días (de tres a ocho era lo común) para después ser conducidos en un tren especial hacia las regiones cafetaleras del interior. En estos primeros días de llegada a Brasil, enferma y muere el único hijo varón, de unos tres años de edad, quedando reducida la familia a cinco miembros: el matrimonio y tres hijas. De cómo eran las circunstancias en estos primeros momentos de la llegada a Brasil hay abundante documentación acerca de las condiciones infrahumanas de la Hospedería de Inmigrantes, cuyas instalaciones previstas para cuatro mil personas acogían a más de diez mil. Los dormitorios eran un salón donde se apiñaban sobre esteras de paja hombres, mujeres y niños. Para los niños las raciones de comida disminuían bastante en proporción a las de los adultos: los niños de siete a once años recibían la mitad que estos, los de tres a siete un cuarto, y los menores de tres no recibian nada. A esta Hospedería acudían los hacendados de las fazendas cafetaleras en busca de mano de obra. Una vez firmado el contrato, cada grupo familiar recibía billetes gratuitos de ferrocarril para dirigirse al lugar más cercano a su puesto de trabajo. Allí se les ofrecía vivienda de madera, generalmente de un solo cuarto con piso de tierra, y un trozo de tierra en usufructo o conuco que garantizaba la subsistencia familiar. A una familia de estas características se les encomendaba el cuido de 500 a 1.000 cafetos (arbustos de café) sin más numerario que el conuco, antes mencionado. Sólo, al recolectar el café, trabajando todos los miembros de la familia a destajo percibían un salario líquido o pagamento. La recolección del café era una tarea comunitaria a la que concurrian todas las familias de inmigrantes que trabajaban en la fazenda. La media de unidades domésticas que había por fazenda oscilaba entre 15 y 25 familias numerosas (de más de seis miembros).

Hay que señalar que muchos de los andaluces que emigraron a trabajar en los cafetales de de las terras rossas de Sao Paulo soñaban con salir de la miseria minifundista de sus aldeas de origen; y al llegar a Brasil se encontraron en peores circunstancias: ya ni siquiera eran propietarios de un pequeño lote de tierra, sino usufructuarios de un conuco, o sea, conuqueros esclavizados a la gran fazen$d a$, muchas de ellas estaban electrificadas sin posibilidad física de escapar. Esta es la historia amarga del café que las historias de vida, contadas por la segunda generación, desde España y desde la ilusión, desconocen u omiten. 
La época dorada del café en Brasil tuvo lugar entre 1889 y 1929, es la época denominada de la República Velha, en la que la región neurálgica del país la constituían los Estados Centrales de Sao Paulo, productor de café, y Minas Gerais, productora de ganado vacuno. Es la época en la que los destinos del país están en manos de una oligarquía feudal, productora de café y leche, la oligarquía del café con leche, de Sao Paulo y Minas Gerais respectivamente. Por esta época en los Estados del norte del país seguirán predominando los decadentes señores feudales de la caña de azúcar y del cacao, estos últimos, armados y con ejército propio de peones de sus fazendas, son los coroneles, inmortalizados en las obras, "Cacao", "Gabriela, clavo y canela" de Jorge Amado. El sur de Brasil (Río Grande do Sul, Paraná, Santa Catarina), colonizado por alemanes e italianos principalmente, poco a poco comenzará a brindarnos una nueva oligarquía estanciera (ganadera) emergente. Los años veinte, y sobre todo el crac del 29, fueron nefastos para la oligarquía cafetalera, la superproducción de este producto había sido un error, la crisis del 29 hizo prescindir a EE.UU. y a Europa de los postres en las comidas, y uno de ellos era el café do Brasil. Por tanto, muchas de las familias que emigraron a Brasil a comienzos del siglo XX, retornarán como unidad biológica incompleta (padres e hijos más pequeños, ya que los hijos mayores se casaron y se arraigaron en el país receptor) a la aldea de origen, como veremos en el testimonio que reproducimos a continuación.

\section{HISTORIA DE VIDA, FAMILIA Y GÉNERO. TANSCRIPCIÓN DEL TESTIMONIO.}

El relato que quiero contar se trata de un hecho real, y es la historia de una mujer (mi madre), nacida en nuestra Andalucia maltratada a comienzos del siglo $\mathrm{XX}$. Esta historia (la informante redactó previamente el relato que nos lee) la presento al Tercer Concurso "Martín Recuerda" en la modalidad de alumna de estas clases de adultos que es una gran idea para ofrecernos una oportunidad (la del estudio) para los que no la hemos tenido antes y podamos aprender algo ahora. Gracias a todo aquel que esté metido en este humanitario trabajo (de la educación de adultos). Mi deseo es aprender para en lo sucesivo mejorar lo que escribo...

Desde que empecé a tener algún entendimiento me interesé por los problemas de los emigrantes, ya que desciendo de ellos tanto por vía materna como paterna. Mi padre nació en Brasil... Era enero de 1901 cuando nació una niña ( $m i$ madre) en casa dc unos humildes agricultores, ella era la $4^{\mathrm{a}}$ hija de aquella familia. Esta niña se llamó Carmen... A primeros de este siglo, en nuestra Andalucía la vida era muy difícil para los trabajadores; el lugar de nacimiento de esta niña era de los más deprimidos de nuestra tierra; con los escasos medios, la niña desde 
que empezó a andar hacía la vida en casa de su abuela materna que vivía a unos cuantos kilómetros de su casa; la niña con su abuela estaba muy bien cuidada, también en la misma casa de su abuela vivía otra hija, también casada, más joven que la madre de la niña; pero sin hijos. La niña seguía creciendo muy encariñada con su abuela y tía. Dada la mala situación por la que atravesaba la familia (los padres $y$ hermanas) de la niña deciden irse para América; tanto la abuela como la tía de la niña les piden que les deje a la niña que con ellos nada le va a faltar, puesto que la pequeña hacienda quedaba en manos de esta hija... La madre no lo ve mal del todo, sabiendo ellos que allí, en América, había que trabajar duro para poder conseguir algo; y aunque no les fuera fácil desprenderse de su hija, ya que el padre se negaba rotundamente..., ya tenían otro hijo más, era un niño (primer y único niño); ya la niña contaba con 5 años de edad. Y llegó el día de la partida y se marchan para Brasil; el padre, desde el puerto de Málaga, quiere volver a por su hija; pero no lo hizo, ya que entonces Málaga quedaba muy lejos' y por los escasos medios de comunicación que había...

Al llegar a Brasil, se enfermó el niño y murió; así que estos padres perdian dos hijos al mismo tiempo (la niña que se quedó en España y el niño que murió nada más llegar a Brasil), tan sólo les quedaban las tres hijas mayores: Matilde, Encarnación y Rosario. ¿Cómo sería la reacción de estos padres en un país extranjero, con otro idioma y lo que acababa de ocurrir.. y gracias que en aquellos tiempos la emigración estaba mejor que hoy?... Las familias que emigraban, en este caso, al llegar a Brasil acudían los patronos, creo que era una casa de Inmigración a donde llevaban a estas personas y las contrataban para sus "fazendas" de cafetales y al trabajar (al comenzar a trabajar) les daban casa y comida a unas gentes que se trasladaban a tierra extranjera por no tener medios en la suya (en el lugar de origen), pues no estaba nada mal... La casa era de madera. Por aquellas fechas había mucha emigración de Italia y otros países; pero los patrones preferían a los españoles. De muy niña sabía que los emigrantes con destino a Brasil desembarcaban en Santos, éste era el puerto de Sâo Paulo. La madre de Carmen, en medio de los sufrimientos gustó Brasil, en aquel país los trabajadores no carecían de nada, era muy diferente a lo que había dejado en España... Ellos en la "fazenda" trabajaban el matrimonio y las dos hijas mayores..., y pronto pudieron comprarse un terreno y trabajar en lo suyo. Este terreno estaba cerca de una gran ciudad a donde esta mujer (mi abuela) acudía con una carreta a que tuvo por el fallecimiento de su hijo pequeño y por haber dejado a su hija en

\footnotetext{
' Málaga estaba situada a 130 kilómetros de la aldea (Rubite) de la que era originaria esta familia. El camino hacia Málaga, bordeando las faldas de una cordillera costera paralela al mar Mediterráneo, era muy dificultoso debido a la falta de pavimento (asfalto) y la accidentada topografia del terreno. El viaje de la aldea hasta la capital portuaria, Málaga, se realizaba en coches de caballos o "diligencias" pudiendo durar unos cuantos días.
} 
España, le vender cosas (frutas y hortalizas); Rosario, que así se llamó esta mujer ( $m i$ abuela), veía que la vida en Brasil era más productiva que en España; aunque ella no podía olvidar a su país, en él había dejado a su hija y a todos sus familiares; pero, por lo pronto, tenían que vivir allí... A los 4 años de llegar a Brasil (en 1910), Rosario tuvo otra hija, ésta se llamó Isabel. Allí seguian con su lucha... En aquellos tiempos había mucho movimiento de gentes de allí para acá o viceversa...Muchos de los que se iban a América regresaban pronto, no todos se adaptaban a vivir fuera de España, así cuando venía a España (desde Brasil) alguien conocido, Rosario enviaba a su hija alguna cosita...

Su hija, Carmen (mi madre), crecía muy feliz y contenta al lado de su abuela y de su tía en aquella humilde aldea, tan pobre..., pero a ella nada le faltaba, sus tíos se ocuparon en que ella aprendiera a leer, a escribir, a coser, bordar, y cuantas cosas fueran necesarias para valerse en la vida... En una palabra, que sus tíos la educaron mejor que a todas las niñas de la aldea y se hizo una mujer de provecho... Carmen, mi madre, viajaba mucho a Motril $^{2}$, allí vivía un hermano de su madre, José López Rubia, que tenía tres hijas solteras y de ellas aprendía muchas cosas (labores del hogar como coser; bordar; etc), se pasaba en Motril muchas temporadas..: Ya Carmen se echó novio, demasiado joven, después de algunos años de noviazgo, se casa a los 19 años (en el año 1920) y antes de cumplir 20 años nació su primer hijo que fallecería a los dos meses de edad, no tardó mucho en tener otra hija... El marido de Carmen ( $m i$ abuelo)había nacido en Brasil (en 1893) y tenía 7 años (en 1900) cuando sus padres regresaron a España...

Mientras tanto los padres de Carmen en Brasil luchaban y cada vez tenían más deseos de volver a España para ver de nuevo a su hija y conocer a su nieta. Sus tres hermanas mayores (Matilde, Encarnación y Rosario) se casaron en Brasil. Isabel, la pequeña, que nació allí, contaba ya con 12 años, cuando sus padres deciden volver (hacia 1922), venden el terreno que compraron y un buen día embarcan para España...Después de muchos días de navegación llegan (a España), entonces aquellos viajes duraban casi un mes...Por lo pronto (al retornar) se instalaron en su humilde aldea donde vivían antes de marchar a Brasil, allí tenían una casa... El encuentro con su hija fue difícil de explicar... ellos que la dejaron con 5 años, la encontraron con marido y una hija..., estaban contentos y daban gracias por hab er podido volver... Los padres de Carmen se marchan pronto de su antigua casa (en la aldea) venden las pocas cosas que allí tenían y con un

\footnotetext{
${ }^{2}$ Motril es la capital comarcal de la costa y de las sierras costeras de la provincia de Granada. La aldeă, Rubite, de la que era originaria esta familia está situada a 7 kilómetros del mar Mediterráneo y en los inicios de la cordillera costera, en un terreno pobre y escarpado. La distancia entre Rubite y Motril era de más de 20 kilómetros por unos caminos accidentados y de tierra.
} 
dinero, que trajeron de Brasil, compran en Minasierra (Motril) 3 un cortijo ${ }^{4}$ que tenía muchos chirimoyos y otros árboles frutales. Esta finca tenía dos viviendas; pero como este hombre (mi abuelo), el marido de Rosario, no entendía los riegos de aquellas tierras, puesto que en la pequeña aldea (de origen, llamada Rubite) era todo de secano, y en Brasil no se regaba; decide que vengan a la finca de Minasierra a vivir su hija Carmen y su marido para que le ayuden a trabajar estas tierras... y todos vivían co ntentos... Desde este cortijo, Isabel iba a Motril para aprender a coser y todo marchaba sobre ruedas... hasta que un dia les avisan desde la aldea que el tío de Carmen se ha puesto enfermo y tienen que regresar Carmen y su marido a la aldea para ocuparse de aquellos campos... El padre de Carmen queda solo en Minasierra y no puede atender el trabajo que aquello tiene; (entonces) vende el cortijo y compra una casa en Motril; al poco tiempo también enfermó este hombre falleciendo pronto, él se llamó Juan y fue mi abuelo. En la aldea el tío de Carmen seguía muy enfermo y no había esperanza de que pudiera mejorar hasta que un día llegó el final de la vida de aquel hombre que se llamó Francisco. En tres meses pieden la vida los dos cuñados. Decían en la aldea que Francisco había enfermado de pena por haberse ido Carmen al cortijo de Minasierra con sus padres; y del padre de Carmen, la gente decía que había enfermado por la misma causa, por macharse Carmen y su marido a la aldea a cuidar las tierras del tío Francisco... En Motril quedó Rosario, ya viuda, con su hija lsabel que contaba 15 años (año de 1925). Esta mujer, Rosario, era muy trabajadora, pone una carbonería para ganar algo, y pensaron regresar a Brasil.

Ella (Rosario) era una enamorada de aquella inmensa nación, que (pues) alli encontró una mejor vida para la clase trabajadora..., además en Brasil estaban sus tres hijas mayores... Rosario habló con su hermana, hija Carmen y yerno, animándolos a ir a Brasil donde los trabajadores vivían mejor que en España... y así deciden irse todos; ya Carmen tiene otra hija más (que era yo, en 1925). Tenían que vender las tierras de la aldea; pero Rosario se impacientaba porque el viaje

\footnotetext{
${ }^{3}$ Minasierra es una zona de montaña suave, muy fértil, situada al oeste del término municipal de Motril (a unos 2 kilómetros de la ciudad), orientada al mar Mediterráneo. Las tierras de Minasierra son regadío. En la actualidad esta próspera zona, de clima subtropical, ofrece una variada gama de productos agrícolas, insólitos en Europa, como chirimoyas, aguacates, etc., que hacen las delicias del mercado español y europeo en general.

${ }^{4}$ Cortijo es el nombre que se da a la casa de campo con terrenos cultivables en Andalucía (sur de España); pero dentro de esta región sureña hay que distinguir dos subregiones, totalmente distintas en paisaje e imaginario: Andalucía Occidental o Andalucía del Guadalquivir y Atlántica (constituida por las provincias de Jaén, Córdoba, Sevilla, Huelva y Cádiz) donde se da un régimen de tenencia de la tierra latifundista (propiedades superio res a 1.000 hectáreas) y en ella el cortijo significa casa-palacio rural y gran propiedad de tierras; Por el contrario, Andalucía Oriental, El antiguo "Reino de Granada" o Penibética (por las montañas que la conforman), bañada por el mar Mediterráneo (constifuida por las provincias de Málaga, Granada y Almeria), dada la accidentada topografia del terreno, ofrece un régimen de tenencia fragmentado, minifundista; por tanto, la vivienda rural llamada también "cortijo" es una casa de campo unifamiliar con un minifundio (unas 3 hectáreas de tierra) alrededor.
} 
no se agilizaba como deseaba. Era 1925, por aquellas fechas la emigración seguía en cantidad... Tenían la carta de llamada que una de las hijas desde Brasil les había mandado para poder ir las 7 personas que componían toda la familia; pero la finca no se vendía y Rosario decidió unirse a otras familias que salían de Motril. Avisó a su hija, yerno y hermana para decirles qaue se marchaban su hija Isabel y ella. Embarcaron en el puerto de Motril hasta Gibraltar desde allí que tenían que coger otro barco para Brasil; pero a la hora de embarcar, según normas que tenían estas navieras, las dejan en tierra, teniendo que permanecer en dicha ciudad (Gibraltar) mucho tiempo por no estar todas las personas (las siete personas) que figuraban en la carta de llamada... así que comprenderán cuánto sufrieron esta mujer y su hija... Al fin ya embarcaron y desde Gibraltar enviaron a Motril otra carta de llamada que habían recibido desde Brasil para que marcharan los que faltaban (a saber: Carmen, su marido, dos hijas pequeñas, y la hermana de Rosario); pero ya no se marcharon se quedaron en la aldea donde siempre habían vivido...

Aquella aldea era muy pobre, era de secano, agua había muy poca, y las tierras que no tienen agua tiene pocos beneficios... Carmen tuvo un hijo más (ya tenía las dos hijas y un hijo)... De Brasil, de vez en cuando, llegaban cartas, Isabel sabía escribir y ella por mandato de su madre era la que escribia a su hermana. Los 3 ó 4 años que vivió en España Isabel le fue muy grato conocer a su hermana Carmen, ésta decía que su hermana (Isabel) encontraba los productos españoles de más perfecta fabricación que los de Brasil.

Rosario y su hija Isabel cuando retornaron a Brasil se fueron a vivir a otra ciudad más grande que la que ella frecuentaba con su carreta a vender hortalizas. A esta nueva ciudad se habían trasladado dos de sus hijas, esta ciudad estaba también en el Estado de Sao Paulo. Como ya no tenian hombres para trabajar el campo, Isabel comenzó a coser para ganarse la vida... vivían en casa de Matilde (la hija y hermana mayor).

Aquí, en España, sería el año de 1931 (o así) Carmen tuvo otro hijo, hacia 1932 fallece en Brasil la hija mayor de Rosario, Matilde dejó 7 hijos. Rosario sigue (viviendo) en casa de su yerno, ocupándose de toda la familia, Isabel que tiene 20 años era ya una gran modista y en la casa de su cuñado pone un taller de costura para que con ella trabajen sus dos sobrinas mayores, hijas de su hermana Matilde, fallecida. De las otras tres hijas fallece Encarnación, quedó Rosario, ésta llegó a una edad avanzada; mi madre (Carmen) no la conoció.

Por el 1933, Carmen tiene otro hijo... Ya tiene una familia bastante numerosa (5 hijos, el matrimonio, y su tía con la que siemppre había vivido). Quiero explicar como era aquella humilde aldea que fue el lugar de nacimiento de esta 
historia: era un terreno de muchas montañas, cuando llovia fuerte aquellas tierras se veían andando hacia abajo por ser todo tan pendiente. La que escribe, to recuerda como unos campos deliciosos sobre todo en primavera, con tanto verdor los almendros, viñas e higueras, y los sembrados con flores, mariposas, los pájaros, todo era precioso, creo que no había campos más bonitos... aquellos campos se sembraban de trigo, garbanzos, guisantes, lentejas, las poquitas aguas que había en los barrancos se recogían en albercas para regar tierras en las que se pusieran hortalizas, patatas, maíz. Los campos, en ganeral eran de almendros, viñas e higueras; pero daban muy poco dinero, por ser tan poca la tierra. La que escribe los veía así: "Ví los campos sembrados de muchas cosas y en los riachuelos lavar las ropas, las flores y volar las mariposas... De aquellos sembrados me quedo con el trigo, hinojos, amapolas..." Aquello era tan pobre que careciamos de todo; pero no sé cómo explicar que nos sobraba de todo... En aquellos tiempos las personas, que allí vivían, creían que no había nada mejor (que aquello) y para los niños lo creían un paraíso... No había ni luz, ni agua, ni carretera; pero mi infancia la recuerdo bonita... donde los niños trabajaban desde muy pequeños y apenas iban a la escuela. Las niñas, siendo ellas pequeñas, tenían que cuidar de sus hermanos pequeños, desde que los niños podían andar se empleaban en trabajos (tareas): unos guardaban cabras; otros espantaban gorriones, a los niños con pocos años los ponían con latas a espantar a los gorriones para que no se comieran el trigo... Los hijos de Carmen no trabajaban tanto como otros niños, ya que sus padres los mandaban a la escuela, sí trabajaban en verano que se hacía la recolección de la almendra, la vendimia; y en invierno recoger los sarmientos que se usaban como leña y quitar las malas hierbas de los sembrados. La tía de Carmen se quedaba en la casa cuidando de los hijos pequeños, fue una mujer extraordinaria, se llamó Gracia, fue una verdadera madre de los hijos de Carmen, ya que ésta tenía que ayudar a su marido en ciertas faenas del campo. Aquellos campos eran muy sacrificados... crecían muy malas hierbas y después de tanto trabajar... no se sacaba nada, si no llovía a tiempo todo se perdía. Allí la mayor producción era la almendra y el higo para secar, estos además de venderse, daban para comer la familia, los de mala calidad servían para cebar a los cochinos, mulos y otros animales... Siendo muy niña vi a mi padre plantar almendros e higueras y ahora quiero recorrer con la mirada hasta encontrar una planta de aquellas que creo tienen más de 60 años... La casa de Carmen era de las mejores de la aldea por ello en ella vivieron unos maestros de escuela... 
Ya en $1936^{5}$ esta familia decide irse a vivir a Motril... Con su propia cosecha de vino que tenían en la aldea sobreviven... Antonio (mi padre) con sus mulos vendía vino... En febrero de 1937 ocurrió la desvandada de Málaga ${ }^{6}$... bombardeos... y deciden volver a la aldea en 1937, allí no podían vivir... Antonio se dedicó con un mulo a vender lo que podía, todos los hijos se le pusieron enfermos de sarampión..., el más pequeño falleció a consecuencia del sarampión a los 15 meses de edad.Carmen y su familia sufren mucho en el tiempo de la guerra y después las cosas siguieron siendo muy difíciles... y ellos como eran tantos todavía más dificil todo. De Brasil durante la guerra civil no tiene ningunas noticias. En el verano de 1937 en uno de los viajes que hace Antonio vendiendo lo que compraba, le intervienen el mulo para los trabajos de los soldados..., este hombre queda desalmado sin tener con que trabajar... se tiene que meter a trabajar en una finca grande y Carmen, acompañada de una de sus hijas, tenía que comprar los alimentos para su numerosa familia, caminando muchos $\mathrm{kms}$ al día, cambiando unas cosas por otras (trueque), con dinero no se encontraba nada: ni alimentos, ni ropa, ni calzados; en fin, una pena los apuros que se pasaban y aparte de los sustos que la guerra tiene y venía acompañada del hambre. Aquí se le agrandan los sufrimientos a esta mujer; por último tienen que trasladarse a otro sitio, ya que en la aldea era imposible seguir..., tienen que dividir la familia entre este nuevo sitio y la aldea, en ésta quedaron la tía, la hija menor y el mayor de los hijos; marchándose de la aldea el matrimonio la hija mayor y los dos hijos más pequeños al

\footnotetext{
${ }^{5}$ El 18 de julio de 1936 marca el inicio de la guerra civil española que dura hasta abril de 1939. La costa y cordilleras mediterráneas de las provincias de Málaga, Granada y Almeria fueron fieles al gobierno de la II República española, legalmente constituido y en el que habian triunfado los partidos de izquierdas (el Frente Popular) en febrero de 1936, lo que provocó el golpe militar de una parte del ejército, de ideología fascista, y que actuaba en el norte de África y en las Islas Canarias, emprendiendo desde estos lugares una "reconquista", llamada "cruzada", de la península hasta hacerse con la capital, Madrid, en abril de 1939. La Andalucía de la costa del Mediterráneo (Málaga, Granada y Almería) vive 7 meses de continuos ataques del ejército fascista hastaı caer bajo su poder en fébrero de 1937.Pero esta guerra civil general (macroguerra) se tradujo en una "miniguerra" de ajustes de cuentas entre los pequeños propietarios rurales, asi pues conflictos centenarios por la linde de una finca o/y por el dominio del agua (de las acequias) y por el ultraje al "honor" familiar' o duelo no concluido, sembraron el pánico y la tragedia en las familias, pues cualquier vecino podia acusar a su rival de tener una ideología distinta a la imperante (si los fascistas ocupaban la aldea se acusaba de "rojo" o comunista al vecino rival; si los de izquierdas ocupaban el lugar bastaba con acusar de "fascista" al rival), y ello era motivo para el incondicional fusilamiento en las tapias (paredes) de los cementerios.Por ello, la guerra civil española, pese a la ideología de los intelectuales, tiene un transfondo de una profunda tragedia rural, casi "lorquiana", en un país dominado todavía en los años treinta por la superstición y por una mentalidad católica reaccionaria, propias de sociedades rurales.

"La "desvandada" ("desvandá") de Málaga se produjo cuando los fascistas ocupan la ciudad de Málaga "pasando a cuchillo" (fusilando) sin miramiento a la población, y abriendo cárceles... Ello provoca una diáspora de todo tipo de personas, incluso delincuentes, hacia los lugares próximos generando caos y matanzas por doquier; así pues, la ciudad de Motril, a unos $100 \mathrm{kms}$ de Málaga, acogió a gran parte de la desvandada lo que generó suma confusión entre sus habitantes.
} 
pueblo de Guadix ${ }^{7}$, en este pueblo era más fácil conseguir los alimentos; pero tenían que hacer muchos viajes para labrar la finca de la aldea y traer víveres a los que quedaron en ésta. Para que se den cuenta como estaban las cosas en tiempos de guerra: uno de los viajes que hizo Carmen y su marido a la aldea, cogieron el tren en Guadix hasta Almería, desde esta capital hasta la aldea se distancian unos $100 \mathrm{kms}$ y se pasaron en Almería unos 14 días, esperando combinación para venirse; al final se vinieron en un carro ${ }^{8}$. Ya un buen día terminó la guerra; pero quedaba otra guerra de miserias y calamidades. Carmen se lo dijo a su tía que tenían que vender la finca de la aldea para sobrevivir, vendieron la finca y poco pudieron remediarse, les pagaron muy poco, la tía de Carmen sufrió mucho ante aquella determinación, ella le tenía mucho cariño a toda aquella tierra, ya que la heredó de su padre; pero no hubo otro remedio. Las hijas de Carmen, las mayores, empezaron a trabajar en los campos donde podían y los hijos, como tantos niños, trabajaron desde muy pequeños en la vega de Motril' ${ }^{\circledR}$ en otros sitios. Carmen sufría mucho de ver la situación en la que se encontraba su familia. Ella también trabajaba muchísimo, siempre pendiente de los suyos, como eran tantos tenía que preparar comida para todos $y$, a veces llevar comida, a otros sitios. Como en aquellos tiempos no había ni pan, esta mujer (Carmen) se las tenía que arreglar de una forma que era para asombrarse..., su tía sufría mucho con tanto esmero como ella la educó. En aquellos años de apuros, como pudo Antonio se compró un mulo y se dedicó a traer aceite, harina, patatas y Carmen los vendía en su casa y se compró un y trozo de tierra, ya entre estas dos cosas sacaban a la familia para adelante un poco mejor...

Ya hubo noticias de Brasil, la madre de Carmen había fallecido, sin saber de ella (de su hija) si le había ocurrido algo en la guerra..., según decía Isabel en sus cartas, el último tiempo de vida de su madre fue mucho lo que sufrió por no tener ninguna noticia de España. Carmen sintió gran pena por las pérdida de su madre... Isabel seguía viviendo en casa de su cuñado con el taller de costura que lo llevaban entre las tres (las dos sobrinas y ella), Isabel compra un terreno para hacerse una casa, este terreno era grande como para tener una pequeña huerta al lado; su hermana Rosario compra otro terreno igual y se hace una casa de madera. En Brasil... hacía muchos años había muchas casas de madera. Isabel hace en

\footnotetext{
${ }^{7}$ Guadix al noreste de la provincia de Granada, estaba a unos $150 \mathrm{kms}$ de la aldea,Rubite, escenario de esta historia.

${ }^{8}$ Un carro era vehículo tirado por bestias (mulos).

"La vega de Motril es de caña de azúcar, el trabajo en ta misma consistía en la zafra o corta dr Trabajo casi de esclavitud, que acogía a los más pobres de las aldeas de Ia comarca. Las cond de vida de los trabajadores de la caña, "macheteros", o "monderos" como se les denomina en li eran totalmente precarias, vivian hacinados en barracones sin agua corriente y $\sin$ tuz. El trabu, temporal (de marzo a junio). Dichos barracones se han mantenido hasta mediados de los años ocnen. ta del siglo $\mathrm{XX}$.
} 
su terreno dos casas pequeñas y las alquila, pues ella seguía viviendo, por motivos de su trabajo de taller de costura, en casa de su cuñado que allí tenía sus clientes.

En España, la familia de Carmen piensa de nuevo en marchar a Brasil. Esta vez se encarga un sobrino, hijo de Rosario, en preparar la carta de llamada y trabajo incluido. Ya las dos hijas de Carmen están casadas, y el hijo mayor también; pero esta vez tampoco van a Brasil, porque Antonio se ve complicado, muy a pesar suyo, pero ocurrió así con esto de los guerrilleros ${ }^{10}$ que había en la Sierra después de la guerra civil de España, ingresó en la cárcel durante algún tiempo... y este fue el motivo de no poder ir a Brasil. Y ya esta familia queda en España definitivamente, casándose los dos hijos que quedaban solteros y ya las cosas marchan mucho mejor.

Isabel se quedó muy triste al no poder ir esta familia a Brasil, ya que había preparado su casa para recibirlos, Isabel estaba casada y no tuvo hijos y vivía en su propia casa, su marido fue empleado de obras públicas, descendiente de Málaga; las otras tres hermanas también se casaron con españoles. Isabel era muy constante escribiéndole a su hermana y le mandaba unas cartas muy extensas contándole muchas cosas de los sobrinos, y como eran 15 sobrinos siempre tenía cosas nuevas que decirle. Estos sobrinos ninguno era del campo, algunos de ellos estudiaron algo, y aunque ninguno se hizo rico, por lo menos vivían dignamente en aquella maravillosa nación que encontró su abuela a principios de siglo, no sé si aquella nación fue verdad como ella la vivió; pero ellos sí que encontraron una mejor vida... Hoy se sabe muy bien que en Brasil hay muchas miserias y el trabajador del campo generalmente vive mal.

La tía de Carmen estaba bastante mayor, esta mujer sufrió muchos en aquellos años después de la guerra civil, para ella su sobrina era su hija y los hijos de ésta sus nietos, los había visto nacer y crecer a todos; los sufrimientos de la guerra (y posguerra) fueron muy fuertes para ella..., un triste día falleció, siendo muy sentida por todos.

\footnotetext{
"Aunque la guerra civil concluyó oficialmente en 1939; sin embargo se inició una segunda guerra clandestina, guerra de guerrillas de signo anarquista, en casi todas las sierras de España. Los que no podian vivir la represión franquista, los que estaban amenzados de muerte, se autoexiliaron en su propia tierra lanzándose al monte, buscando "enlaces" 0 intermediarios que les proporcionaran de viveres o bastimentos. Fue una guerra, la del "maqui", que duró hasta 1960 , y que, pese a la represión de la guardia civil en el ámbito rural, tuvo el apoyo faniliar de las aldeas próximas a las sierras.Para acercarse al conocimiento de la guerrilla en la provincia de Granada es aconsejable la obra de ESTÉVEZ CALLEJON, J.: La guerrilla antifranquista en la Alpijarra (1946-1952).La partida de Paco, el polopero.
} 
Isabel cambia de trabajo, al parecer por hacerle compañía a una sobrina, hija de su hermana Rosario, esta sobrina se llamó Iracema, se había casado y se marchó a vivir a un pueblo, cercano a Baurú, donde se llevó a su madre cuando ya no se pudo valer y allí falleció a su lado, era la única hija que tenía, los demás eran varones, por este motivo le dejan a Iracema el terreno que compraron sus padres, Iracema emprende un negocio para ganarse la vida y hacer la casa que no pudieron hacer sus padres, este negocio (de Iracema) consistía en viajar mucho a Sao Paulo de donde traían prendas de vestir que después vendían en Baurú. Como Iracema era joven su tía la acompañaba para que estos viajes no los hiciera sola, Isabel, ya no necesitaba trabajar, había cosido mucho, ya tenía su casa, su marido tenía su trabajo, y como no tuvieron hijos, tenían sus ahorros. En este negocio estuvieron varios años, los suficientes para que Iracema hiciera su casa, la hizo pero no la pudo disfrutar, enfermó de cáncer y falleció muy joven; Isabel quedó muy triste ya que era una sobrina muy querida por ella. Isabel, por no tener hijos estaba muy querida por todos sus sobrinos y los hijos de estos, que vivían al lado.

También el marido de Carmen enferma del corazón, permaneciendo varios años enfermo, este hombre había trabajado mucho en tantas cosas..., de esta enfermedad sin remedio falleció a los 76 años (hacia 1970) toda la familia sintió esta pérdida, y Carmen más que nadie quedó muy triste.

Carmen seguía aquí en España, al lado de sus hijos y recibiendo las cartas de su hermana Isabel, que como ya he dicho antes, le escribia unas cartas de mucho contenido. Tanto una como la otra cada vez que recibían una carta era como si se visitaran. Carmen estaba muy sedienta de su familia de Brasil que no había conocido. Esta mujer (Carmen) falleció con el deseo... de viajar a Brasil y conocer por lo menos a sus sobrinos..., pero no tuvo la oportunidad de ir. Un día recibió Carmen una gran alegría de su hermana Isabel, ésta le dice en una carta que viene a España, el marido de Isabel había fallecido, y ya con 74 años viaja a España sólo por ver a su hermana, Carmen tiene 83 años (año de 1981), este viaje lo hace con una nieta de su hermana Rosario y su marido y otro matrimonio joven, vinieron 6 personas: los dos matrimonios, Isabel y otra señora, viuda de otro sobrino, hijo de su hermana Matilde, fallecida hacía muchos años. Carmen se esmeró mucho preparando su casa para recibir a su hermana... y el día de la llegada viajó a Granada acompañada de todos sus hijos. Llegaron por la tarde al aeropuerto de Granada...El encuentro fue maravilloso, esto ocurría en 1982.Se pasaron un mes juntas las dos, muy contentas. Canmen, a sus 83 años, hacía la comida para las tres; los otros dos matrimonios jóvenes se marcharon a viajar por ahí. Isabel estaba muy mal de las piernas, peor que Carmen, aunque tenía 9 años menos; pero este mes que pasaron juntas fue maravilloso, visitaron con uno de los hijos de Carmen, la cueva de Nerja, la Alhambra de Granada, Almeria... Ya los 
malísimos tiempos que pasaron los hijos de Carmen quedaron lejos y, aunque siguen siendo pobres; pero por lo menos ya todo es mejor que antes. Una vez que pasó el tiempo que tenían previsto los dos matrimonios jóvenes de permanecer en España, vinieron a recoger a Isabel y a su acompañante, fueron a Barcelona para visitar a la hija mayor de Carmen que vivía allí, ya contaba 60 años, aquella niña que Isabel conoció pequeñita cuando vino de Brasil, ya habían transcurrido 57 años. Desde Barcelona marcharon nuevamente para Brasil.

Carmen el tiempo que vivió recordó la visita de su hermana con gran alegría, ya enfermó pronto en 1983, falleciendo en 1984, a los 84 años; el último tiempo que vivió enferma perdió la razón, y se pasaba el tiempo, según decían sus hijas, hablando con sus hermanas y con su madre y así terminó sus días esta gran mujer que tanto sufrió y trabajó para sacar adelante a su numerosa familia. La que escribe tuvo la suerte de conocerla, vivir siempre a su lado para que le contara su vida y podersela transmitir a los demás.

Igual que les expliqué cómo era aquella humilde aldea donde comenzó esta historia, quiero contarles cómo está en la actualidad, yo he estado allí en este último año, aquello se ha empobrecido totalmente o se ha desertizado, como ahora no llueve como antes, aquellos campos ya no producen apenas nada, sólo quedan los almendros, la viñas se han perdido todas, es muy raro ver un trocito de viña, allí que se podía comer uvas por todos los sitios que se pasaba; las pocas aguas que hay en los barrancos no se aprovechan; ya se ha marchado toda la juventud; yo recuerdo en mi infancia que en aquellos campos había 9 cortijadas ${ }^{11}$ y residían unas 150 familias, hoy no llegan a 20 personas las que viven allí; total son campos abandonados, muchas casas caídas, y todos aquellos inmensos campos se ven cubiertos de maleza, ya no se hacen sembrados. La que escribe, a pesar de todo, tiene a aquello gran cariño, y si no estuviera tan dificil llegar hasta allí iría más, fue donde ella dio sus primeros pasos.

Isabel siguió escribiendo a sus sobrinas, como siempre lo hiciera a su hermana, y recordaba como algo sensacional el haber venido a España, según me decía su sobrina, desde que hizo este viaje se iba deteriorando su salud... En 1989 escribió a su sobrina la última carta, ya muy mal escrita, veía muy poco, había perdido mucha vista, falleciendo en 1990.,así terminó su vida la última de las hijas de aquella familia que en 1905 emigraron a Brasil encontrando allí una mejor vida de la que habían dejado en España

\footnotetext{
"Cortijadas: conjunto de cortijos o pequeñas viviendas rurales diseminadas por el medio natural montuoso de la cordillera costera de la Andalucía del Mediterráneo.
} 
Desearía la que escribe que todo el que sale de su país de origen, encuentre un campo donde trabajar y una casita, aunque sea de madera, como aquellas que les daban a los inmigrantes en las fazendas de cafetales...Por lo menos unas condiciones de vida dignas. Desearía que existan naciones que necesitan mano de obra extranjera igual que la de los españoles que fueron necesitados en otras partes del mundo..., y que no se camine hacia atrás, que cada día se mejore, aunque fuera poco... No hace tanto, los que tenemos tantos años, hemos visto a los españoles ir y venir con sus maletas a muchas naciones europeas, yo he conocido a muchos de estos, de allí traían algún dinero para poder solucionar alguna cosa; otros siguen viviendo en estos países. A mí la emigración me preocupa y me da mucha pena, aunque sea en condiciones normales, y si es al contrario siento gran pena. 